\title{
CONTRIBUTION OF LEARNING INDEPENDENCE ON THE ACHIEVEMENT OF MATHEMATICAL LEARNING OUTCOMES OF GEOMETRY TRANSFORMATION MATERIALS SCHOOL STUDENTS
}

\author{
Nida Fathiya Hanifah ${ }^{1}$, Syifa Nur Saifanah ${ }^{2}$ \\ ${ }^{1}$ SMK Pasundan 3, Jl. Melong Raya No. 2 \\ ${ }^{2}$ SMK Plus Darussurur, Jl. Nanjung Kp. Panyaweuyan \\ ${ }^{1}$ nidnfhani@gmail.com, ${ }^{2}$ syifasaifanah@gmail.com
}

\begin{abstract}
This study aims to determine the relationship between self regulated learning and learning outcomes in the learning of geometric transformation of high school students in Cimahi, West Java. The type and analysis data of this study are included in quantitative research. The method used in this study is a survey method with correlation techniques. The population in this study were all students at SMPN 10 Cimahi, the number of samples in this study were 30 students in grade 9. Data collection techniques used non-test instruments in the form of self regulated learning scale, while learning outcomes variables used school archive documentation. The results showed that there was a significant linear relationship between self regulated learning and student learning achievement, with $26 \%$ contribution of self regulated learning to student learning outcomes in geometric transformation material and $74 \%$ influenced by other variables.
\end{abstract}

Keywords: Self regulated learning, Achievement of learning outcomes, Geometry transformation

\begin{abstract}
Abstrak
Penelitian ini bertujuan untuk mengetahui hubungan antara kemandirian belajar dengan hasil belajar pada pembelajaran transformasi geometri siswa sekolah menengah di kota Cimahi, Jawa Barat. Jenis dan data analisis penelitian ini termasuk dalam penelitian kuantitatif. Metode yang digunakan dalam penelitian ini adalah metode survei dengan teknik korelasi. Populasi dalam penelitian ini adalah seluruh siswa di SMPN 10 Cimahi, jumlah sampel dalam penelitian ini sebanyak 30 siswa kelas 9. Teknik pengumpulan data menggunakan instrumen non tes berupa skala kemandirian belajar, sedangkan variabel hasil belajar menggunakan dokumentasi arsip sekolah. Hasil penelitian menunjukkan bahwa terdapat hubungan liniear yang signifikan antara kemandirian belajar dengan prestasi hasil belajar siswa, dengan kontribusi kemandirian belajar sebesar 26\% terhadap prestasi hasil belajar siswa pada materi transformasi geometri dan $74 \%$ dipengaruhi oleh variable lain.
\end{abstract}

Kata Kunci: Kemandirian belajar, Pencapaian hasil belajar, Transformasi geometri.

How to Cite: Hanifah, N.F., Saifanah, S.N. (2020). Contribution Of Learning Independence On The Achievement Of Mathematical Learning Outcomes Of Geometry Transformation Materials School Students. JEE, 3 (1), 31-38. 


\section{INTRODUCTION}

Mathematics has an important role in education. Because mathematics is able to form mindsets because mathematics accustoms the mind to discipline and obeys the rules of the rules. This is in line with the importance of mathematics according to Ruseffendi (Zanthy, 2016), which is to assist in calculations, science for scientists, as a mindset guide and as an attitude maker. Therefore mathematics subjects are studied starting from elementary, secondary, to tertiary levels of education. In addition, mathematics is considered very important because in everyday life humans can not be separated from mathematics. one of them is the concept of calculation that helps facilitate commerce. Like the opinion of Novtiar \& Aripin, (2017) which states that mathematics is an activity of human life, which means that mathematics is used in everyday life by all groups.

Given the importance of mathematics, ideally learning goals at school can be achieved to the maximum. But in reality, in the process of learning mathematics at school has not reached its maximum goals, it is seen from the student's learning achievement which is relatively low. This is in line with a survey conducted by the Program for International Student Assessment (PISA) (Asep, 2016) which is held every 3 years since 2000 on the education system and the ability of school students, in fact, Indonesia ranks second lowest in the field of science mathematics.

One of the mathematical material that has an important role in the development of student mathematics is the material of geometry transformation. as the opinion of Edwards (Albab, Hartono, \& Darmawijoyo, 2014) which revealed that learning geometry transformation provides opportunities for the development of spatial visualization abilities and geometrical reasoning so that mathematical proofing abilities are obtained by students. Geometry transformation material is taught to the ninth grade students of junior high school (SMP), which is the uppermost grade level at the junior high school level. This is because geometric transformation material requires high-level thinking. This is in line with three main reasons why students should learn the transformation geometry proposed by Hollebrands (Albab et al., 2014), which gives students the opportunity to think about important mathematical concepts (such as symmetry, functions, etc.), providing a context that is make students think that transformation geometry involves various disciplines, and allows students to engage in activities that use higher-order thinking in many ways.

Geometry transformation material also needs to be mastered by students because students' ability to think about important concepts in mathematics (one of which is symmetry) that students can get through mastering geometry transformation material will be used in analyzing mathematical situations. According to NCTM (Albab et al., 2014) students are required to be able to analyze mathematical situations using transformation and symmetry. Based on the importance of geometry transformation material, students should be able to master the concept of geometry transformation. But in reality mastery of geometry transformation material is still low. This can be seen from the achievement of low student learning outcomes. As in the research of Tunnisa, Rizal, \& Karniman (2016), and the research of Dewi, Khodijah, \& Setiawan, (2020) which states that student learning outcomes on geometry transformation material are still low.

Many factors can affect the acquisition of student learning outcomes in the form of external and internal factors. Besides the acquisition of student learning outcomes is also influenced by students 'cognitive abilities and students' affective abilities. One of the affective abilities of 
the many affective abilities of students which is a factor is learning independence. This is reinforced by the opinion of Mardapi (Linda \& Sudira, 2015) that the success of a study is not only determined by cognitive abilities but must also be supported by students' affective abilities which include responsibility, behavior, discipline, willingness to learn, independence and others.

Independence of students' mathematical learning plays an important role in the learning process because learning independence is a way of learning students based on their own desires, consequently the learning strategies used by students according to the circumstances of each individual. According to (Amalia, Syafitri, Sari, \& Rohaeti, 2018) the ability to learn independence owned by students will require students to be active in learning, both when learning takes place or before or after. The goal is that students' mathematical problems can be effectively solved.

This is supported by the opinion of Hargis and Kerlin (Isnaeni, Fajriyah, Risky, Purwasih, \& Hidayat, 2018) revealed that self-regulated learning is the making of plans and selfobservation carefully in completing academic tasks through cognitive and affective processes, students with high learning independence tend to be better in self-control, able to observe, assess, and manage to learn effectively and manage time efficiently to complete the task.

Indicators of learning independence according to Sumarmo (Isnaeni et al., 2018) are (1) willing to learn with or without the help of others; (2) analyzing their own learning needs; (3) formulating/choosing learning goals/targets; (4) selecting and using sources; (5) choosing a learning strategy, and checking the learning outcomes; (6) able to collaborate with others; (7) construct meaning; and (8) self-control.

Based on the description above the students' learning independence in learning mathematics is assessed to have an impact on the achievement of mathematics learning outcomes. Then this study was conducted to see how much student achievement is influenced by learning independence in geometry transformation material. So that the following problems can be formulated, 1. Whether student achievement in mathematics learning is influenced by learning independence. 2. How much independence learning affects student mathematics learning achievement. The objectives expected to be achieved from this study are 1. To find out whether or not there is an influence on the achievement of students' mathematics learning outcomes by learning independence. 2. How much the independence of learning affects the achievement of student mathematics learning outcomes.

\section{METHOD}

This study uses a survey method with correlation techniques, which are looking for a relationship between student learning achievement and student learning independence. To predict how far the change in the value of the dependent variable if given a change in the value of the independent variable is used regression analysis. The independent variable (X) and the dependent variable (Y) in this study include learning independence $(\mathrm{X})$ and student learning outcomes $(\mathrm{Y})$.

The population of this research was all students of SMPN 10 Cimahi, the sample was taken by random sampling technique, with the subject of the sample being 30 students of 9 th grade. The instrument used was the non-test instrument in the form of a learning independence scale consisting of 20 statements with 4 choices of opinions that were strongly agreed (SS), agree 
(S), disagree (TS), and strongly disagree (STS). The answers are measured with a Likert scale of 1 to 4 . Whereas for learning outcomes data use documentation techniques which are to obtain data on the learning outcomes of grade IX students at SMPN 10 Cimahi. The calculations in this study were assisted with the use of SPSS and Microsoft Excel.

\section{RESULTS AND DISCUSSION}

\section{Results}

The following will be presented the results of the study in the form of a general description of the independence of student learning and student achievement. Normality test results to find out whether the data are normally distributed. Correlation test results to find out how the relationship influences student learning independence and student learning outcomes. Test the coefficient of determination to determine the magnitude of the contribution of student learning independence and student learning outcomes and Test the significance of regression to determine the magnitude of the influence of student learning independence and student learning outcomes.

Table 1. General description of student achievement and independence.

\begin{tabular}{llllrr}
\hline Variable & $\mathrm{N}$ & Max & Min & mean & \multicolumn{1}{c}{$\begin{array}{l}\text { Standar } \\
\text { deviasi }\end{array}$} \\
\hline Learning achievement & 30 & 100 & 70 & 88.66667 & 10.98065 \\
Learning independence & 30 & 83.75 & 60 & 71.33333 & 6.3308 \\
\hline
\end{tabular}

Based on table 1 the average student achievement is 88,66667 and the standard deviation of student achievement is 10.98065 which means that the data distribution is quite high. For the independence of student learning with an average of 71,33333 and a standard deviation of 6.3308 which shows low data distribution.

Table 2. Results of normality tests of student learning independence and learning achievement.

Tests of Normality

\begin{tabular}{|c|c|c|c|c|c|c|}
\hline \multirow{2}{*}{} & \multicolumn{3}{|c|}{ Kolmogorov-Smirnov $^{\mathrm{a}}$} & \multicolumn{3}{c|}{ Shapiro-Wilk } \\
\cline { 2 - 7 } & Statistic & $\mathrm{df}$ & Sig. & Statistic & $\mathrm{df}$ & Sig. \\
\hline $\begin{array}{c}\text { independence of } \\
\text { learning }\end{array}$ & .089 & 30 & $.200^{*}$ & .971 & 30 & .576 \\
student achievement & .216 & 30 & .001 & .851 & 30 & .001 \\
\hline
\end{tabular}

a. Lilliefors Significance Correction

*. This is a lower bound of the true significance.

Based on table 2, seen from the Shapiro-Wilk section, the sig value for student learning independence is 0.576 while student achievement is 0.001 . from these results, it can be said that only independent learning is normally distributed because it has sig $\geq 0.005$. while the achievements of students who have sig $<0.005$ can be said to be not normally distributed.

Table 3. Correlation test results of student learning independence and learning achievement. Model Summary

\begin{tabular}{|l|r|r|r|r|}
\hline Model & $\mathrm{R}$ & $\mathrm{R}$ Square & \multicolumn{1}{c|}{$\begin{array}{c}\text { Adjusted R } \\
\text { Square }\end{array}$} & $\begin{array}{c}\text { Std. Error of the } \\
\text { Estimate }\end{array}$ \\
\hline 1 & $.510^{\mathrm{a}}$ & .260 & .234 & 9.612 \\
\hline
\end{tabular}

a. Predictors: (Constant), independence of learning 
Based on table 3 , the value of $\mathrm{R}$ is a symbol of the correlation coefficient. The correlation coefficient value is 0.510 which is in the medium category. From the table above there is also the value of $\mathrm{R}$ square or Determination coefficient of $26 \%$ which shows that the independent variable $(\mathrm{X})$, namely learning independence contributes $26 \%$ to learning achievement as the dependent variable (Y). and the remaining $74 \%$ is influenced by other factors beyond learning independence.

Table 4. Results of regression tests of student learning independence and learning achievement.

ANOVA $^{\mathrm{D}}$

\begin{tabular}{|ll|r|r|r|r|r|}
\hline Model & & Sum of Squares & df & Mean Square & F & Sig. \\
\hline 1 & Regression & 909.814 & 1 & 909.814 & 9.848 & $.004^{\mathrm{a}}$ \\
& Residual & 2586.852 & 28 & 92.388 & & \\
& Total & 3496.667 & 29 & & & \\
\end{tabular}

a. Predictors: (Constant), Learning independence

b. Dependent Variable: student achievement

Based on table 4 , the value of sig $<0.05$ is 0.004 which indicates that the regression equation model based on research data is significant, meaning that the regression model meets the linearity criteria.

Table 5. Results of regression tests of student learning independence and learning achievement.

Coefficients $^{\mathrm{a}}$

\begin{tabular}{|c|c|c|c|c|c|c|}
\hline \multirow{2}{*}{\multicolumn{2}{|c|}{ Model }} & \multicolumn{2}{|c|}{ Unstandardized Coefficients } & \multirow{2}{*}{$\begin{array}{c}\begin{array}{c}\text { Standardized } \\
\text { Coefficients }\end{array} \\
\text { Beta }\end{array}$} & \multirow[b]{2}{*}{$\mathrm{t}$} & \multirow[b]{2}{*}{ Sig. } \\
\hline & & $\mathrm{B}$ & Std. Error & & & \\
\hline \multirow[t]{2}{*}{1} & (Constant) & 25.555 & 20.188 & & 1.266 & .216 \\
\hline & Learning independence & .885 & .282 & .510 & 3.138 & .004 \\
\hline
\end{tabular}

a. Dependent Variable: student achievement

Based on table 5, it is known that the regression equation model is $\mathrm{Y}=25,555+0.885 \mathrm{X}$

\section{Discussion}

Based on the results of research on 9th-grade students at SMP Negeri 10 Cimahi obtained a significant relationship between learning independence with the achievement of student learning outcomes in the material transformation geometry by $26 \%$. The contribution of learning independence is not so great on student achievement, this is because student achievement can be influenced by several other factors, such as students' physical conditions, teacher attitudes towards students, and attitudes of the closest people to one of the parents. This is supported by Yuzarion's research (Yuzarion, 2017) which suggests that there is an influence of teacher attitudes toward students, parents' attitudes towards students and learning independence on student achievement.

Nevertheless, learning independence still has an important role in student learning outcomes. Because students with high learning independence will be able to improve the quality of their learning so that the achievements of their learning outcomes will increase. This is corroborated by Fasikhah's research (Fasikhah \& Fatimah, 2013). It appears that the group given the learning independence training has better learning achievement than those not given the training. This is also reinforced by Latipah's research (Latipah, 2010) which shows the 
results of learning independence provide a positive influence on the achievement of student learning outcomes.

According to Mujiman (Aliyyah, Puteri, \& Kurniawati, 2017) learning independence is a learning activity that consists of knowledge possessed, both in the selection of study time, ways of learning, and evaluation of learning carried out by students themselves. In terms of learning material, students' needs in mastering certain materials will be seen if he understands their abilities, so students can find out where their difficulties are and find solutions that are right for themselves. This can increase student learning independence.

So that learning independence becomes an aspect that can determine student achievement. Students need learning independence to be able to develop their potential, especially in learning mathematics so that students can independently solve the problems they face. Therefore learning independence must be increased to achieve maximum learning outcomes.

\section{CONCLUSION}

From the results of this study, the conclusion obtained is that there is a positive and significant relationship between learning independence and student mathematics learning achievement. Learning independence is very needed in the learning process because students with high learning independence will be able to deal with problems related to learning material so that learning achievement will increase.

Learning independence has a contribution of $26 \%$ to the achievement of student learning outcomes and $74 \%$ is influenced by other variables. Learning independence examined in this study is learning independence associated with the achievement of student learning outcomes in geometry transformation material. The next researcher is expected to be able to examine the independence of learning towards the achievement of learning outcomes in other material.

\section{REFERENCES}

Albab, I. U., Hartono, Y., \& Darmawijoyo. (2014). Kemajuan Belajar Siswa pada Geometri Transformasi Menggunakan Aktivitas Refleksi Geometri. Jurnal Cakrawala Pendidikan, 3(3), 338-348. https://doi.org/10.21831/cp.v3i3.2378

Aliyyah, R. R., Puteri, F. A., \& Kurniawati, D. A. (2017). Pengaruh Kemandirian Belajar Terhadap Hasil Belajar Ipa the Influence of Independence Learning To Natural Sciences Learning Outcomes. (October 2017). https://doi.org/10.30997/jsh.v8i2.886

Amalia, A., Syafitri, L. F., Sari, V. T. A., \& Rohaeti, E. E. (2018). Hubungan Antara Kemampuan Pemecahan Masalah Matematik Dengan Self Efficacy Dan Kemandirian Belajar Siswa SMP. Jurnal Pendidikan Matematika Inovatif, 1(5), 887-894.

Asep, S. egok. (2016). Kemampuan Berpikir Kritis dan Kemandirian Belajar dengan Hasil Belajar Matematika. Jurnal Pendidikan Dasar.

Dewi, D. K., Khodijah, S. S., \& Setiawan, W. (2020). Analisis motivasi belajar matematika siswa sma bingkai cendekia cililin berbantuan aplikasi geogebra pada materi transformasi geometri. JPMI, 3(1), 49-58. https://doi.org/10.22460/jpmi.v3i1.p49-58

Fasikhah, S. S., \& Fatimah, S. (2013). Self-regulated learning (SRL) dalam meningkatkan prestasi akademik pada mahasiswa. Jurnal Ilmiah Psikologi Terapan, 01(01), 145-155.

Isnaeni, S., Fajriyah, L., Risky, E. S., Purwasih, R., \& Hidayat, W. (2018). KEMANDIRIAN BELAJAR SISWA SMP PADA MATERI. 2(1), 107-115. 
Latipah, E. (2010). Strategi Self Regulated Learning dan Prestasi Belajar : Jurnal Psikologi, 37(1), 110-129. https://doi.org/10.22146/JPSI.7696

Linda, S., \& Sudira, P. (2015). Faktor-Faktor Yang Mempengaruhi Prestasi Belajar Praktik Kejuruan SMK Program Studi Keahlian Teknik Komputer Dan Informatika. Jurnal Pendidikan Vokasi.

Novtiar, C., \& Aripin, U. (2017). Meningkatkan Kemampuan Berpikir Kritis Matematis Dan Kepercayaan Diri Siswa Smp Melalui Pendekatan Open Ended. Prisma, 6(2), 119-131. https://doi.org/10.35194/jp.v6i2.122

Tunnisa, M., Rizal, M., \& Karniman, T. S. (2016). Penerapan Pendekatan Pendidikan Matematika Realistik pada Materi Transformasi untuk Meningkatkan Hasil Belajar Siswa di Kelas IXa SMPN 1 Tanantovea. Jurnal Elektronik Pendidikan Matematika Tadulako, 5(2), 44-51.

Yuzarion. (2017). Faktor Yang Mempengaruhi Prestasi Belajar Peserta Didik. Ilmu Pendidikan, 2(1), 107-117.

Zanthy, L. S. (2016). Pengaruh Motivasi Belajar Ditinjau Dari Latar Belakang Pilihan Jurusan Terhadap Kemampuan Berpikir Kritis Mahasiswa Di Stkip Siliwangi Bandung. Teorema: Teori Dan Riset Matematika. 
38 Hanifah, Saifanah, Contribution Of Learning Independence On The Achievement Of ... 